\title{
Factors to Consider During and After Job Loss or Displacement from Coronavirus 2020
}

Journal of Psychology and Neuroscience

Brief Communication

Bernard F. Pettingill ${ }^{1 *}$ and Federico R. Tewes ${ }^{1}$

${ }^{1}$. Department Of Medicine, LSU Medical Centre(Ret.)

\author{
Correspondence author \\ Bernard F. Pettingill \\ Consulting Economist LSU Medical Centre(Ret.) \\ New Orleans \\ LA 70112 \\ USA \\ Tel: $561-346-7828$
}

Submitted : 28 Jun 2020 ; Published : 12 July 2020
In the year 2020, many people will undergo two of the top five stressful life events, namely a major illness or job loss. In fact, over 45 million Americans are unemployed because of COVID-19 in the workplace today.In addition to contracting coronavirus in the workplace, many other concerns affect individuals today:

1. Taking a financial loss $(24 \%)$

2. Being furloughed $(22 \%)$

3. Experiencing mental health issues $(20 \%)$

4. Having to care for a family love one $(19 \%)$

5. Experiencing first time issues with working from home $(15 \%)$

6. Balancing childcare activities (14\%). All these concerns were recognized by more than 1,035 individuals surveyed by Indeed.com in a recent article published March 24, 2020 [1].

In addition to possible job loss, numerous individuals have had to redeem sick leave benefits and vacation time to offset reduced income, reduced contract work, and decreased paid leave. Employers are acutely aware that rehiring of personnel may be financially taxing in that a smaller market share and less demand for services will have a significant impact on rehiring.

The government has come to the rescue, in part, by providing 26 weeks of unemployment compensation benefits and possibly 13 to 20 weeks of extended benefits under the CARES Act, as a direct result of the COVID-19 pandemic. But these are band-aid solutions to the major problems that occur in this work environment. The majority of individuals who have lost their jobs ( $46 \%$ of the respondents in the above survey) have suffered because their skills are required on site: auto shop mechanics, retail attendants, grocery store clerks, restaurant personnel, healthcare professionals and others are forced to provide their services in a setting whereby demand is on-site and not by working from home. Most of these on-site jobs were never designed to accommodate social distancing regulations of 6 feet or more.

The principal focus of this article is not blue-collar or pinkcollar employees, but instead white-collar workers who have been displaced because of the COVID-19 virus. Industry lingo in Silicon Valley refers to white-collars as Knowledge Workers, according to several Silicon Valley employees interviewed for this article. Because of the 45 million unemployed, it is very probable that a large percentage will re-enter the workforce in a new career, in a new setting, and with a new starting base salary or wage. Ultimately, they may have to start new retirement benefit plans, even though many may have built up retirement benefits in a tenured track position before the virus broke out. The U.S. Department of Labor reported 1.5 million people filed for unemployment benefits for the 13th consecutive week in which the U.S. witnessed over one million in new unemployment claims. Since mid-March, roughly 45.7 million people have now filed for unemployment.

According to ABC News, white-collar employee discussions of layoffs on Glassdoor have jumped $47 \%$ among information technology firms and $64 \%$ in finance. Such discussions have nearly doubled among healthcare workers citing many doctors' offices and other health providers have cut back on nonessential procedures, and some are completely shedding jobs. Furthermore, the software company Toast, which works with the restaurant industry, cut half its workforce $-1,300$ people - citing a dizzying drop in restaurant sales. Yelp, the customer review site, cut 1,000 jobs. Groupon, the online discount company, shed 2,800 jobs [2].

With respect to the rehiring of younger employees, they are not likely to commit 30 years to a single company, the way 
Baby Boomers did in their professional lives. Today, Silicon Valley represents one of the pinnacles of high-salaried positions, like Wall Street jobs during the 1980's. In Silicon Valley, many employees can perform job transfers more easily, given the large number of technology projects like Immersive Technologies (Virtual Reality and Augmented Reality) and Artificial Intelligence, for example. Many young Silicon Valley employees seek a career growth that helps influence early stages of Immersive Technologies and Artificial Intelligence. However, COVID-19 forced companies like Facebook to close their Menlo Park headquarter until January 2021, forcing approximately 15,000 Facebook employees to work remotely from home or other cities outside San Francisco [3].

According to two founding partners of a Silicon Valley-based law firm that primarily represents venture-backed technology startups and emerging companies, their company is dedicated to helping clients manage employee stock options in order to maximize both the ongoing incentives and the ultimate wealth creation for founders, employees, and shareholders. Quoting one of the partners questioned: "As a startup grows, it should move from (1) granting restricted stock-actual company shares that vest as certain requirements are met; to (2) stock options that give employees the choice of buying company shares at a set price; and potentially to (3) restricted stock units that convert into actual company shares upon vesting" [4].

It should be noted that the Apple has recently issued restricted stock of $\$ 2,500$ per employee, which coincides with a Republican tax overhaul of a one-time tax break, paying $15.5 \%$ tax on the repatriated cash of approximately $\$ 250$ Billion, rather than the $35 \%$ tax it would have had to pay previously. The company had set aside $\$ 36.3$ Billion for the eventuality that it would have to pay taxes on the repatriated cash hoard, which has amounted to \$39.1 Billion [5].

Although most job transfers boil down to financial decisions, many individuals overlook how to rigorously evaluate hidden considerations. This is particularly true when trying to evaluate different retirement packages by separate companies. Younger technology employees must now decide between stock options and Restrictive Stock Units (RSU) as ways to receive equity in the company. Compensation methods that can be analyzed in a qualified present value study to compare salary and benefit figures.

In a recent request by a client from the West Coast, who was considering transferring from a $9+$ year position with a reputable company in Los Alamos, New Mexico to a slightly smaller but equally reputable company in San Francisco, California, salary was not the only distinguishing dealbreaker. This 54-yearold healthy married man with no children at home had a life expectancy of 26 years and a work life expectancy of 13 years. His spouse was expected to live another 30 years, and likely to outlive the client's retirement payment plan. Consequently, the pension benefits in present value dollars carried far greater weight for determining a possible job transfer than salary alone. According to the analysis, there were many hidden facts to consider.
First, the original job in Los Alamos, New Mexico meant a cost-of-living $5 \%$ above the national standard of living costs for employees in the United States. Salary was $\$ 236,000$ with an immediate vested pension that used a fixed formula based on longevity, and company match contributions to the vested pension. According to calculations, the New Mexico job provided a present value of $\$ 3.2$ million from today until retirement age 65 .

Second, the job offer in San Francisco automatically faced a cost-of-living $17 \%$ above the national standard of living costs for employees in the United States. Starting salary was over $\$ 337,000$ but the pension did not vest until 10 years and did not have the same company match as the original job in Los Alamos. According to calculations, the San Francisco job offer had a present value of $\$ 4.8$ million from today until retirement age 65 .

In instances when the person must give up a pension plan for the new job offer which has a pension with no vesting, the differences over work life and life expectancy are tremendous. The only way to determine whether or not the trade-off is equitable is to provide an Excel spreadsheet comparison with assumptions built into the calculations for cost-ofliving adjustments, salary and pension benefit match by the company, and the probability that both the employee and his/ her spouse will have a normal life expectancy. Additionally, the probability of remaining employed in that particular position until retirement at age 65 are difficult decisions that on face value look beneficial to the recipient who may realize over a $\$ 100,000$ plus increase in salary, but when the numbers are examined, blending fringe benefit packages such as vacation, sick leave, holiday pay, incentive compensation, moving expenses, spousal insurance, plus retirement benefits, the choice becomes blurry and almost impossible to choose between the two job.

Furthermore, when a company offers the possibility of early retirement with adjustments to the retirement plan based on the number of years of longevity, this is another indication that the figures must be examined in greater detail than on face value. Bonuses also must be considered; a bonus in one company versus no bonus in another company could translate into a huge differential over time when the figures are projected out into the years toward retirement and reduced to present value in order to translate the numbers into comparable current day measures.

Additionally, there are non-economic factors that must be considered. For example, daily commute to work, close proximity to cultural events, provisions for travel, closeness to shopping and city life, air quality, water quality, nearness to family members, and many other options that should be considered when making a determination for job transfer or accepting a new position. 
The only comparable means of equating job one and job two is to lay out all these options, impute values for cost-of-living and company percentages of pension contributions as stated in published payment booklets before any comparison can be forthcoming.

Companies today have a leg up on the millions of unemployed individuals who became unemployed due to the coronavirus. Certainly, any steady income stream is better than no income stream. Flexible spending accounts, disability insurance, life insurance, accidental death and dismemberment insurance, dental plans, and legal expense plans are all variables that should be considered but often get washed out when making selections based on salary alone. Sometimes it boils down to whether or not at age 54 someone is willing to take the risk of transferring to an entirely new city, selling their homestead, establishing a new home base with respect to city and state taxes, and many other options that should be weighted in the balance.

Only a thorough analysis, weighting the pros and cons of all these variables, plus qualified present value analysis of the figures, only then can a decision be made to hopefully reduce the stress of job loss or job displacement during and after the Coronavirus of 2020.

\section{References}

1. SURVEY: The Top 8 Concerns of People around the Impact of COVID-19. https://www.indeed.com/careeradvice/career-development/covid-19-survey Published 24 March 2020

2. Rugaber Christopher (2020) "Layoffs and pay cuts are now striking more white collar jobs" Associated Press Economics Writer. Published 16 April 2020.

3. Tewes Federico R (2020) "Silicon Valley Compensation Methods." Phone Interview. 21 June 2020.

4. "Stock Options and Other Equity Compensation Strategies (2020) Founders Circle." Founders Circle Capital, 15 Jan. 2020, www.founderscircle.com/when-startups-shouldgrant-restricted- stock-iso-nso-rsu-equity/. Accessed 22 June 2020.

5. Lovejoy Ben (2017) "US Tax Bill Passes, Allowing Apple to Repatriate Its \$252B Foreign Cash, but There's a Catch" 9 to 5Mac, 21 Dec. 2017, 9to5mac.com/2017/12/21/ustax-bill-apple/.

Copyright: (C2020 Bernard F. Pettingill. This is an open-access article distributed under the terms of the Creative Commons Attribution License, which permits unrestricted use, distribution, and reproduction in any medium, provided the original author and source are credited. 